\title{
Towards Enhanced Resilience in City Design: A Proposition
}

\author{
Rob Roggema ${ }^{1,2, *}$
}

1 Van Hall Larenstein University of Applied Sciences, Velp 6880 GB, The Netherlands; E-Mail: rob.roggema@wur.nl; Tel.:+31-06-1322-0598.

2 National Institute for Design Research, Swinburne University of Technology, Hawthorn, VIC 3122, Australia

Received: 21 December 2013; in revised form: 5 May 2014 / Accepted: 16 May 2014 /

Published: 5 June 2014

\begin{abstract}
When we use the urban metabolism model for urban development, the input in the model is often valuable landscape, being the resource of the development, and output in the form of urban sprawl, as a result of city transformations. The resilience of these "output" areas is low. The lack of resilience is mainly caused by the inflexibility in these areas where existing buildings, infrastructure, and public space cannot be moved when deemed necessary. In this article, a new vision for the city is proposed in which the locations of these objects are flexible and, as a result, the resilience is higher: a Dismantable City. Currently, the development of this sort of city is constrained by technical, social, and regulatory practice. However, the perspective of a Dismantable City is worthwhile because it is able to deal with sudden, surprising, and unprecedented climate impacts. Through self-organizing processes the city becomes adjustable and its objects mobile. This allows the city to configure itself according to environmental demands. The city is then able to withstand or even anticipate floods, heat waves, droughts, or bushfires. Adjustability can be found in several directions: creating multiple layers for urban activities (multi-layer urbanism), easing the way objects are constructed (light urbanism), or re-using abandoned spaces (transformable urbanism).
\end{abstract}

Keywords: resilience; adaptation; adaptive capacity; Dismantable City; urban metabolism; light urbanism; urban design 


\section{Introduction}

Resilience is defined as "the capacity of a system to absorb disturbance and reorganize while undergoing change so as to still retain essentially the same function, structure, identity and feedbacks" [1,2]. It includes the ability to learn from disturbance [3]). A core question of resilience theory is how resilience in a system could be increased. In the context of this paper, the systems in question are urban-ecological and socio-ecological systems; psychological resilience (e.g., [4,5]); and the physical properties of material [6] or resilience engineering [7], are beyond the scope of this article. The theoretical framework relating to resilience (e.g., [2]) and resilient cities (e.g., [8]) focuses strongly on the mechanics of the system or the city, but to date, this has not resulted in more resilient cities. Concrete, practical directions on how to build a resilient city are often lacking, even when the metabolism of the city is known in detail (e.g., [9]).

One key element of resilience theory is the capability of a system to bounce back, or rearrange the functions or elements of the ecosystem according to the requirements imposed by the environment, or external shocks. The city, by its built nature, has a limited capacity to rearrange its built objects, such as buildings and infrastructure. In this article, this is seen as the key obstacle to increasing resilience. A further key aspect of resilience is that the system should anticipate future impacts and potential change. This implies a design requirement to create a plan for building cities, which are flexible whenever required in the future.

The role herein for design, urban design, landscape architecture and urban planning, is up till the present day limited, a reason to propose a "Dismantable City", which, in this article is defined as: "A city with urban elements or objects, such as buildings, and (parts of) streets, sewage or other infrastructure, which can be freely (re)arranged. In this city, both functional and physical parts are seen as temporary, allowed to change their location and/or function". The word dismantable does not exist in the English language. Dismantle does exist, defined as: take (a machine or structure) to pieces. We use dismantable to express the potential to take (the city) apart. Hypothetically, the mobility of elements enhances the flexibility of spatial configurations, hence, increases resilience. Especially when huge (climate) impacts are expected, the capability to change is paramount. Within the context of this article, social aspects are not considered.

The argument will be made that principles drawn from the fields of self-organization and complexity need to be used in urban design in order for urban systems to be genuinely more resilient. Furthermore, it will be argued that the concept of the Dismantable City offers a concrete method for this application of self-organization and complexity in urban design, and, hence, that the Dismantable City offers a novel way of designing urban and social systems, which will increase those systems resilience.

Section 2 will define resilience and adaptive capacity and will explain their foundations in existing research. It will also make clear how aspects of self-organization increase the resilience of a complex system. Section 3 presents a city as a complex (eco)system, which, as such, would benefit from self-organization when a higher degree of resilience is desirable. In Section 4 the metabolism that results from current planning practice is discussed, with its effects on (the lack of) resilience. In Section 5 the Dismantable City is offered as a self-organizing alternative to current urban design, applying the best principles of self-organization to urban elements. Three examples of the Dismantable 
City from existing planning practice are provided in Section 6. Finally, constraints to implementation of the Dismantable City from current planning practice are discussed.

\section{Adaptive Capacity}

Resilience, or adaptive capacity, is one of three properties of the adaptive cycle and is defined as " $a$ measure of its vulnerability to unexpected or unpredictable shocks... (that) can be thought of as the opposite of the vulnerability of the system" [10]. An adaptive cycle alternates between long periods of aggregation and transformation of resources and shorter periods that create opportunities for innovation. This cycle is seen as fundamental to understanding complex systems, from cells to ecosystems to societies. For ecosystem and socio-ecological system dynamics that can be represented by an adaptive cycle, four distinct phases have been identified:

(1) Growth or exploitation (r)

(2) Conservation $(\mathrm{K})$

(3) Collapse or release $(\Omega)$

(4) Reorganization $(\alpha)$

The adaptive cycle exhibits two major phases (or transitions). The first, often referred to as the fore-loop, from $\mathrm{r}$ to $\mathrm{K}$, is the slow, incremental phase of growth and accumulation. The second, referred to as the back-loop, from $\Omega$ to $\alpha$, is the rapid phase of reorganization leading to renewal [11]. The $\alpha$-phase is especially important for the resilience of the system [12]:

"As the phases of the adaptive cycle proceed, a system's ecological resilience expands and contracts. The conditions that occasionally foster novelty and experiment occur during periods in the back loop of the cycle, when connectedness, or controllability, is low and resilience is high (that is, during the $\alpha$-phase). The low connectedness, or weak control, permits novel re-assortments of elements that were previously tightly connected to others in isolated sets of interactions. The high resilience allows tests of those novel combinations because the system-wide costs of failure are low. The result is the condition needed for creative experimentation."

Generally, resilience is seen as a property of socio-ecological systems, allowing the system to bounce back and recover from an external shock. Adaptability is the capacity of actors to influence resilience [1]. The collective capacity to manage resilience determines whether actors can successfully avoid crossing into an undesirable system regime or return to a desirable one. Actors may use four ways to influence resilience:

- Move thresholds;

- Make the threshold more difficult to reach;

- Move the system away from the threshold;

- Avoid loss of resilience by managing cross-scale interactions.

The question is, however, whether these principles are applicable to city design. To a certain extent they are, for instance in the way water, nature, and social structures are designed. It is beneficial for the sustainability of the city to include nature, cleaner water and inclusive social environments in designs. 
However, do these features still function in disaster-like circumstances, or when the risk landscape changes from predictable changes towards uncertain and unprecedented climate events $[12,13]$ ?

The city needs to be able to constantly change its shape, its functionality and its urban fabric under the influence of external shocks and to relocate urban objects when necessary [14]. Four key properties of resilience, enhancing flexibility and adaptability of built environments and communities, can be defined [15]. These are the need to: create redundancy, which provides free space where new functions may fit, increase diversity multiplying the number of different objects, transform towards a larger modularity where modules can be easily disconnected from others, and allow for feedback through which objects can mutually interact, develop self-organization, and find optimal spots. These properties form a preliminary set of guiding principles for building resilience into city design.

According to Walker et al. [1], the core element in increasing adaptability is the opportunity of agents to manage resilience. These agents, which we call urban objects when talking about cities, need space to move around and be flexible as to where and how they habituate. This implies a "comfortable chaos" [16] in which too much organization can be a bad thing. Comfortable chaos emerges when the city regenerates ( $\alpha$-phase) and creates the space for adjustments, repair, change, and innovation. This happens in times of crisis, when there is a certain mess and room for mistakes.

\section{The City as an (Eco)system}

In order to dig deeper into the resilience of the city, the city needs to be viewed as a system. Complexity theory is very helpful here. Prigogine and Stengers, who studied non-linear dynamic systems [17,18] and Kauffman, who studied self-organization [19], are considered the founding fathers of Complexity Theory. The first researchers to adopt their ideas were natural scientists and physicists. As computers became more powerful, however, their ideas also found their way to researchers working on computer simulations of social systems and artificial life [20]. Nowadays, many scholars use features of Complexity Theory in studies of a broad range of natural and human systems. Complexity Theory is seen as a science enabling the gap between social and natural sciences to be bridged [17,21-24]. Complexity Science has developed from studying closed systems to the study of open systems, including real-life situations, in a wide range of social sciences [25-36]. The sudden unexpected change from one attractor into another, as well as aspects of dealing with the uncertainty of possible unexpected change, have been thoroughly examined. Although spatial planning is deeply rooted in a control paradigm [37], the outcome of a planning process can differ greatly from the intended outcome. Hence, the results can be highly surprising and spatial planning intrinsically has to deal with uncertainty and fuzziness [38-41].

Odum used an analogy of electrical energy networks to model the energy flow pathways of ecosystems [42]. This played a significant role in developing his approach to systems and is recognised as one of the earliest instances of systems ecology. Thinking in sources, production, consumption and losses inspired many to use this language in thinking about the city as an ecosystem. It was especially useful when the cities' environmental problems needed to be solved.

The city is conceived as a dynamic and "double" complex ecosystem [43]. The social, economic and cultural systems cannot escape the rules of abiotic and biotic nature. Guidelines for action will have to be geared to these rules [44]. 
Combining this idea with the concept of urban metabolism [45], a method to analyse cities and communities through the quantification of inputs (water, food, and fuel), outputs (sewage, solid refuse, and air pollutants), and tracking their respective transformations and flows, led to the extended urban metabolism model [46], which has been further elaborated by many [8,47-52]. In this model (see Figure 1), the inputs (flows, sources, stock) are defined that enter the urban system. Under the influence of many exogenous factors, these are transformed, producing sources for use in the city and leading to certain environmental qualities, waste and a certain liveability. To improve sustainability the ingoing flows need to be reduced, the internal processes improved, waste reduced and both environmental quality and liveability improved.

Figure 1. Extended urban metabolism model (adapted from [51]).

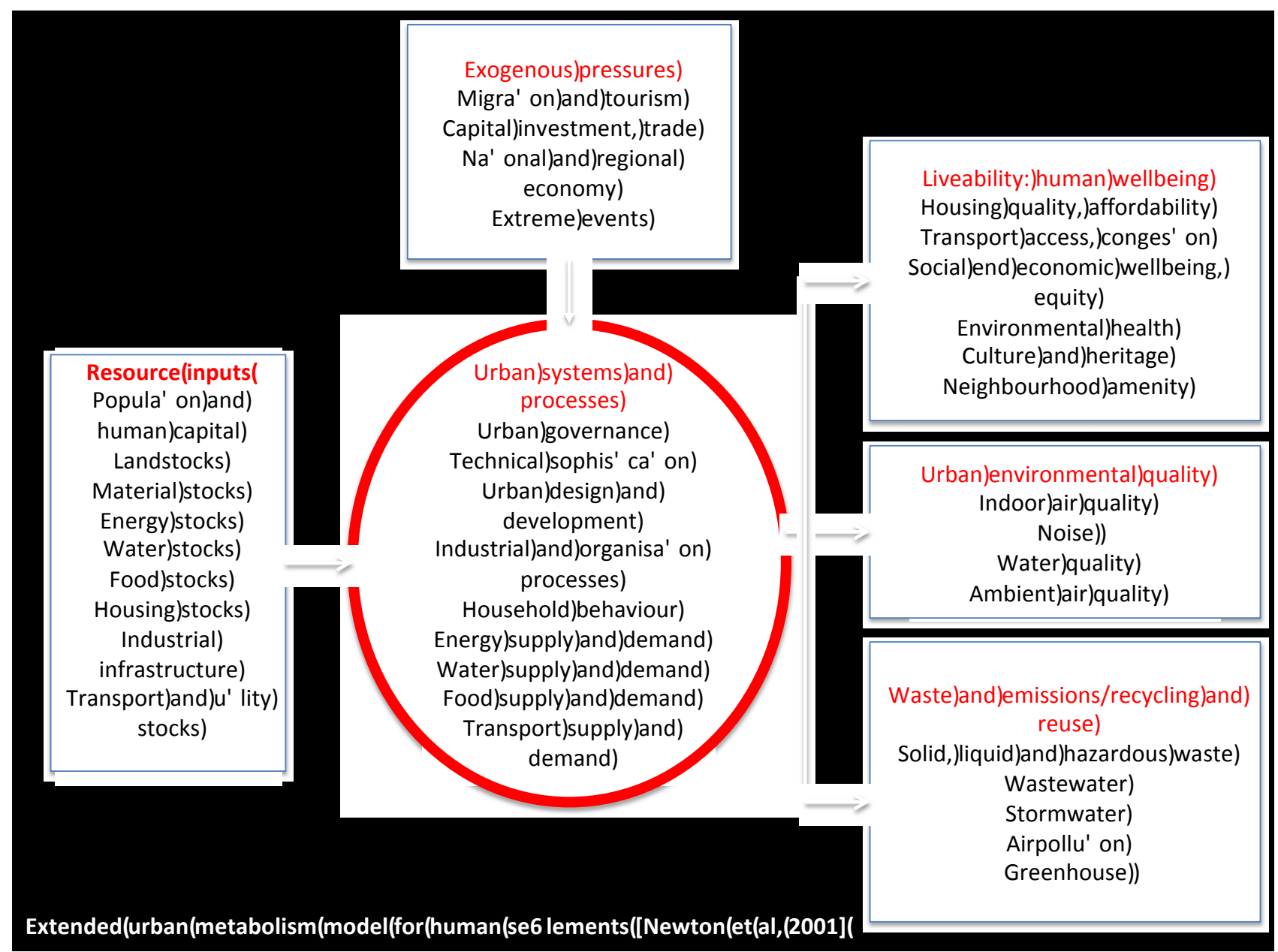

This model of a system with input, internal processing and output is then applied to a city. Odum's scheme is adapted to a 3D image with in- and outgoing flows and detailed with environmental parameters, divided over several layers (derived from [53]) (Figure 2, [54]). 
Figure 2. Combining the layer components of the urban system with in- and out-going flows: Kristinsson's environmental system [54].

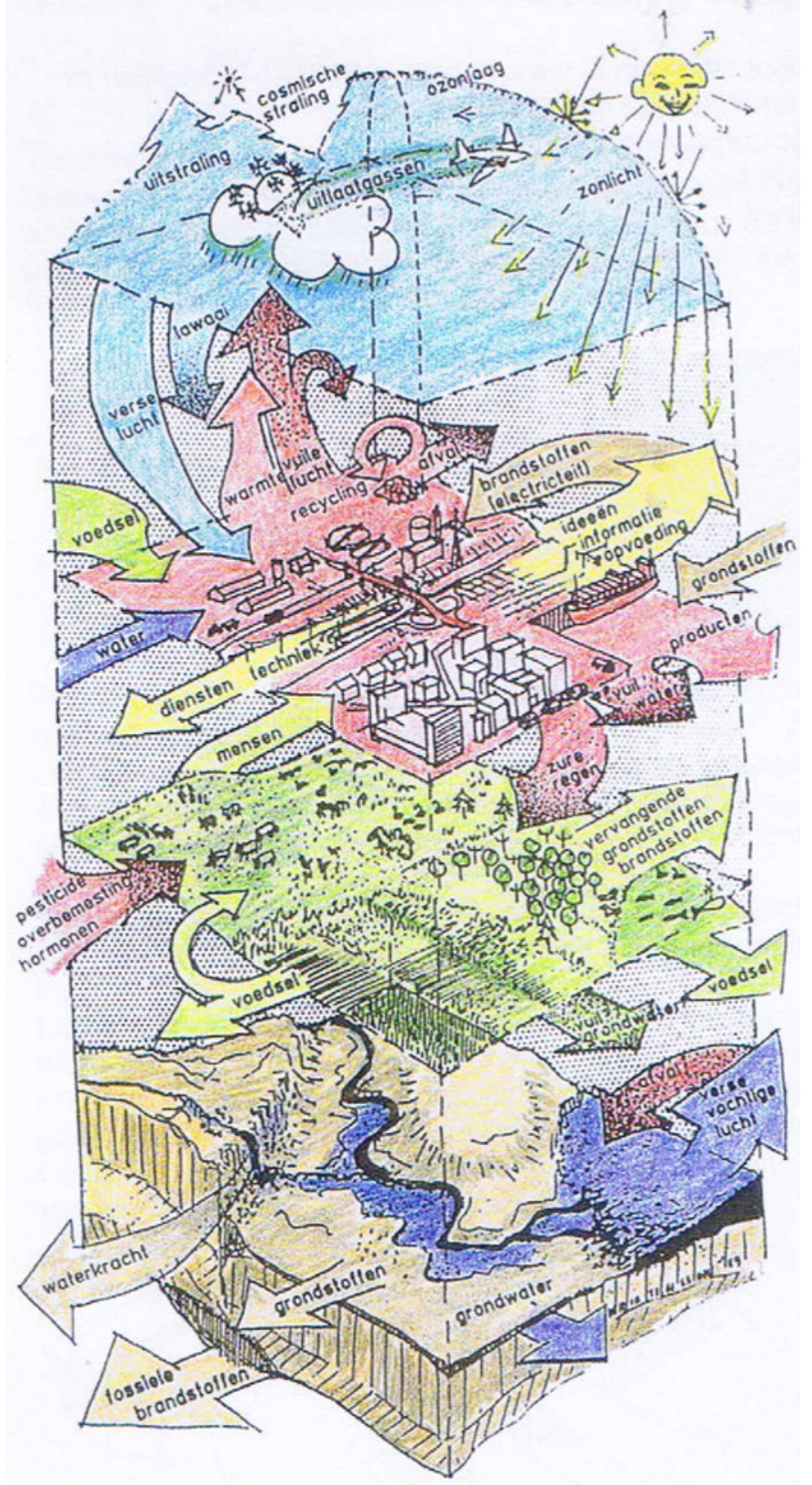

This gives us the parameters to measure or assess the sustainability of a city, but can it also enhance the resilience? In order to achieve this, the city must be capable of regenerating constantly, of reconfiguring its layout and of relocating urban objects. This must be done in a way that reduces the need for external sources, can be adjusted to changing exogenous pressures, can produce efficiently, can reuse and harvest what is available in the city, and can provide a liveable, clean environment that produces no or minimal waste. The city can only perform in this way when urban objects have the opportunity to self-organize, defined as "the potential to spontaneously and unpredictably develop new forms and structures by itself out of chaos" [55], i.e., to be able to "freely" move around and find new locations in interaction with others and the exogenous environment. This can only happen when these 
objects are dismantable and reorganizable in a permanent search for the optimal spots in each circumstance. In many cases the reconfiguration of the urban object itself may be sufficient, for instance when heat waves strike, or a blizzard hurts the city, but not in all circumstances this is sufficient. In case of a flood or bushfire, events with a clear geographical impact, adjusting the urban objects only could not prevent them from vanishing. Here, mobility is key.

This is the Dismantable City: where urban objects can be reconfigured and, when necessary, be taken apart, reused, and relocated.

\section{Support of Current Planning Methods for Enhancing Resilience}

The metabolism that results from current spatial planning practice visualized as an (eco)system with flows that enter and leave the system, is not very sustainable. These types of systems generally consume landscape, produce money, and leave an inflexible mono-functional urban environment. The result is a static urban environment far from resources or the central city, consisting of unattached half-acre blocks, dependent for jobs, food, water, and energy on incoming sources and leaving the environment with waste and pollution. In other words, the urban metabolism of current city planning is not sustainable, nor does it enhance resilience. Land-use in cities uses resources, in the form of food, fossil fuels, water, and energy. The majority of resources used are finite and only marginally renewable. Further metabolism thinking has been focused on a linear throughput of resources through the city, aiming to use finite resources and flows more efficiently, i.e., with fewer leftover materials. Recently, circular metabolism is promoted as a form of city development in which these leftover materials, preferable to renewable resources, are recycled and reused back into the urban system. Given the idea that a sustainable (eco)system is resilient by definition, the problem is not the resilience of the system itself, but the translation of resilience concepts in urban planning and design. Therefore, the following discussion focuses on the way planning approaches support a more resilient development (or not). It implies that a linear planning methodology, if it would embrace a circular metabolism, at least should become circular itself, set aside the option of being non-linear. In the recent planning theory discourse, there are clear signals to replace mono-rationality, for the ease of the argument equated to linearity, with more complex and self-organizing methods of planning, which take into account uncertainty, flexibility and emergence.

Planning theory supports, though presently in a very limited way, a move away from a non-innovative state of mono-rationality [56], which generally conceives of only one way of "good" planning [57] that is dominated by the government, in close association with developers. In order to establish planning without tightening and dictating regulations, current planning practice must be replaced by an alternative, that has been variously described as: post-anarchistic, or autonomous planning creating a disordered order of "becoming" spaces [58]; planning from "outside inward" [59]; informal, insurgent, planning [60]; planning by surprise, making use of coincidental opportunities [61]; or poly-rational unsafe planning [56]. This alternative looms when the fundamental properties of Western planning mono-rationality, namely "playing by the rules", "repeat habitual prior experiences", and "creating a non-innovative status quo" [56], all withstanding self-organization and indirectly resilience, are left behind. Then, "liquid, turbulent or even wild boundaries of both planning thought and spatial territory can occur-literally, to do 'it' without the safety of a condom!" [56]. This is a 
planning practice that takes risks, accommodates difference and encourages the new and creative. In this Dismantable City, physical and functional mobility will be possible and a city is built that is constantly adaptable and resilient. However, before replacing the existing planning system, no matter how inaccurate, an alternative must be studied further or, for the time being, both planning approaches should co-exist.

\section{A Dismantable City?}

The proposition of a Dismantable City is new. The following principles have been identified:

(1) Dismantle building components in order to reuse them in other configurations again.

(2) Create urban objects that are detached from their environment.

(3) The identification of specific zones where mobile elements can relocate in periods of change/turbulence.

(4) Developing plug-in infrastructure where mobile urban objects can attach.

There have been only a few movements that show similarities with the Dismantable City concept, such as the Plug-In-City conceived by the Archigram group, consisting of a framework only to be occupied by plug-in objects [62,63], or Superuse [64] concepts, which "superuse" available flows and resources and connect them into urban ecosystems [65]. The idea is derived from building practice in which the option to disassemble building elements, deconstruct the building and reuse the parts in another building has been long studied. Deconstruction focuses on giving the materials within a building a new life once the building, as a whole, can no longer continue, by "carefully dismantling a building in order to salvage components for reuse and recycling" [66]. Taking it one step further, the adjustability of building components can be increased by programmatic labelling and tagging of building elements, enabling buildings to customize temporary desires or changing demands, so that the building elements perform swarming behaviour [67-69]. At a larger scale, modular buildings have similar ambitions. For instance, the Habitat 67 project in Montreal (Figure 3) is a residential structure consisting of separate, functional apartments that can be put together in a variety of ways. As people move in or out, units can be reconfigured as desired [70]; although it must be mentioned that, in practice, this has not happened very often.

In areas under threat of flooding propositions of floating cities are well known, for instance for the London Theems Gateway (e.g., [71]) and in cities, such as Bangkok, Hanoi, or Djakarta. More common examples can be found in the USA, where living on House Boats is not very unusual, or the recent developments in the new urban development of IJburg, Amsterdam, where a substantive section of the new housing is floating on the water. Experimental landscape design for a region under threat of flooding, where housing follows and moves towards places that are out of the danger zone is the design for the Floodable Landscape in the Eemsdelta region in the Netherlands [72].

At the next level of urban environments and cities, poly-rational planning approaches provide the freedom to experiment with emergent behaviour and self-organization of urban objects. If governmental rules exclude these alternative urban developments, cities will ever face difficulties to become more resilient. Moreover, it must be physically possible to move urban objects around and allow for self-organization to reach the highest possible adaptive capacity. The city must not only be dismantable 
but potential configurations must also be understood and simulated (there is a need to identify the places that the objects would be likely to move to), in order to prevent random, unwanted movements.

Figure 3. The Habitat 67 project in Montreal (Picture: Ifte Ahmed).

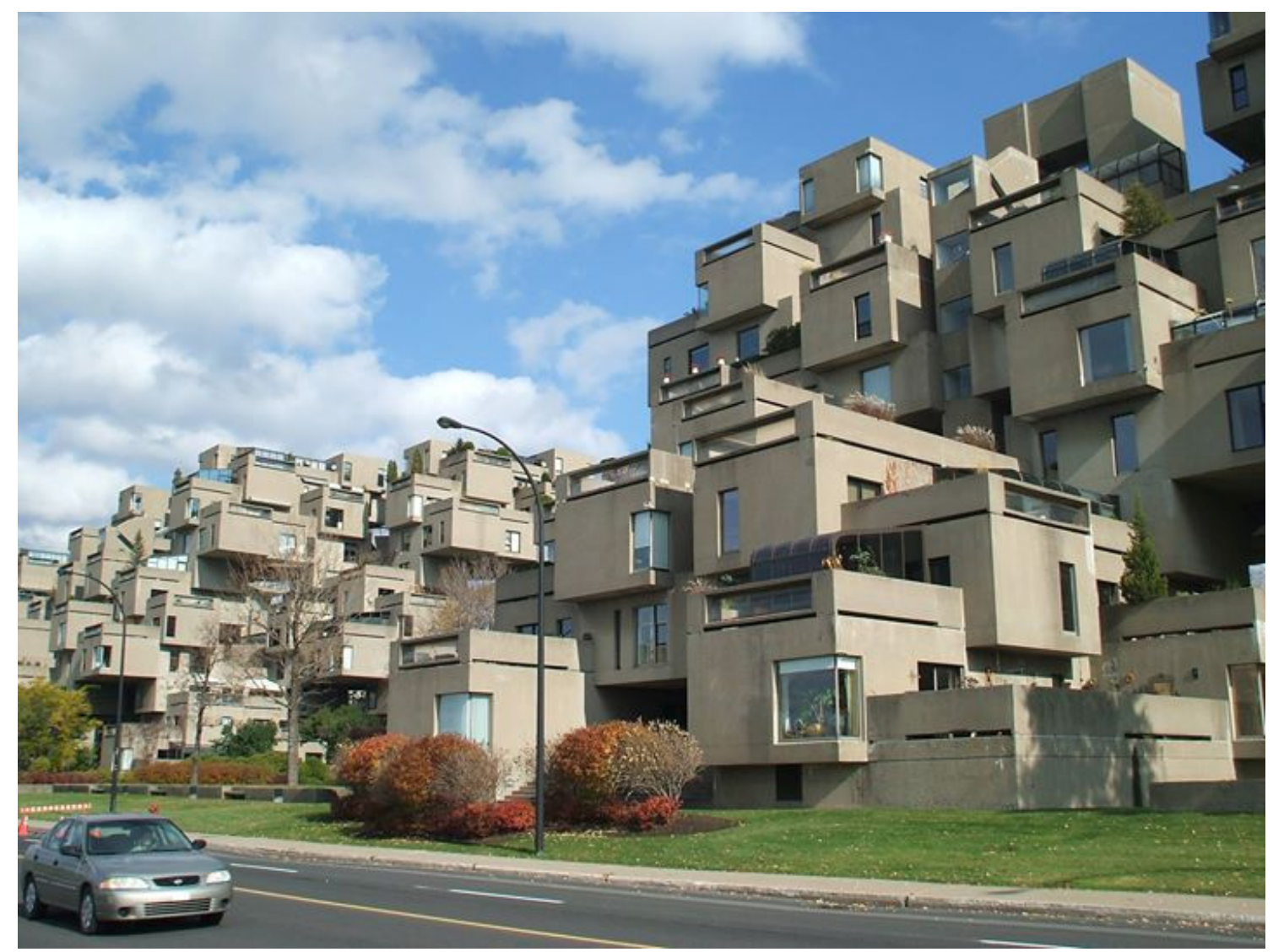

Here, it is necessary to understand the dual complexity of the city: the city as a whole is a complex adaptive system, as is each of its parts [43,73,74]. In nature, such systems exhibit swarm behaviour [75]. Swarms [76,77] are self-organizing systems that prepare for and respond to changing circumstances, achieving this through (a) the interactions taking place between a large number of similar and free moving "agents", which (b) react autonomously and quickly to one another and their surrounding, resulting in (c) the development of a collective new entity and a coherent larger unity of higher order [75]. When swarm behaviour is applied to cities, higher levels of adaptive capacity can be achieved when active interventions on both levels of the "dually complex" city are planned. Current theory describes the process of an evolving system becoming unstable, reaching a crisis, "tipping" and transforming through self-organization to another stable state. Tipping points are identified after they have occurred [78], or identify the patterns that announce these points [79], but they are not planned. In the case of climate change, this system change would preferably be anticipated before the actual event (the disaster) occurs. Hence, an early (active) intervention would initiate self-organizing processes of the urban objects, allowing the system to "flip" to a system state with a higher adaptive capacity that is less vulnerable. Network theory (see for instance [80-85]) holds the key to identifying the intervention point [86]. The type of intervention cannot be determined other than through the local context (existing city combined with climate impact). At the level of urban objects, interactions allow them to develop emergent properties, to self-organize and to change [87]. Provided 
the objects are mobile, the principles of self-organization of a (urban) system will direct the city to move towards an optimal stable state, both at the level of the entire system (e.g., city) and its parts $[43,73,74]$, as these mobile objects then always try to reach the best places in the "fitness landscape" [88-90]. The first attempts to use this thinking in design have been undertaken in building, attributing swarm characteristics to building components [67-69] and in the landscape, attributing landscape objects with complex adaptive systems properties [91]. Extended research is currently under way [92] to simulate urban precincts through agent-based modelling of mobile urban objects under the influence of an external (climate) impact that initiates the process of self-organization. Through the simulation, the ways to enhance adaptive capacity can be determined before a real hazard impacts the area.

For this to happen, it is crucial to create urban objects that can be dismantled and allowed to reconfigure when external influences require it. Therefore, physical mobility of the dismantable elements is required, and space must be created in the urban fabric to allow objects to move and nest in new locations. The next section will describe three urban concepts in which this space and mobility is created: the multi-layer, the light, and the empty city.

\section{Multi-Layer, Light and Empty Cities}

Once it is understood that urban objects must have the opportunity to be mobile, existing built structures need to be adjusted in order to allow new functionalities to be developed (see for instance Section 6.3), and the urban environment needs to offer spaces where these mobile objects can move. The technical constructive research required for the former is out of scope for this article; regarding the latter, there are three urban typologies in which these new spaces are sought. While these examples may be inspiring, they also require a realization strategy to prevent them from ending in vain. The "learning by doing" strategy, in which flows, actors and areas come together, [44,93,94] may prove useful.

\subsection{The Multi-Layer City}

There are many designs that propose vertical cities, wherein a single skyscraper-type structure may contain an entire city, including gardens and vertical forests (e.g., [95]). However, very limited research is available regarding how extra space can be created in ordinary neighbourhoods for unknown future functions or urban objects seeking alternative places.

The multi-layer city is a hypothetical urban design, developed in a Design Lab environment, in which more free spaces are created by extending the useable layers. Apart from the ground level, currently used for green space, transport space, and private land, four additional layers can been identified (Figure 4). This makes it possible to move and relocate urban objects in different layers and positions when desirable. The level of choice quadruples. 
Figure 4. The four layers of the multi-layer city: (a) the underground, (b) ground level, (c) rooftop and (d) air.

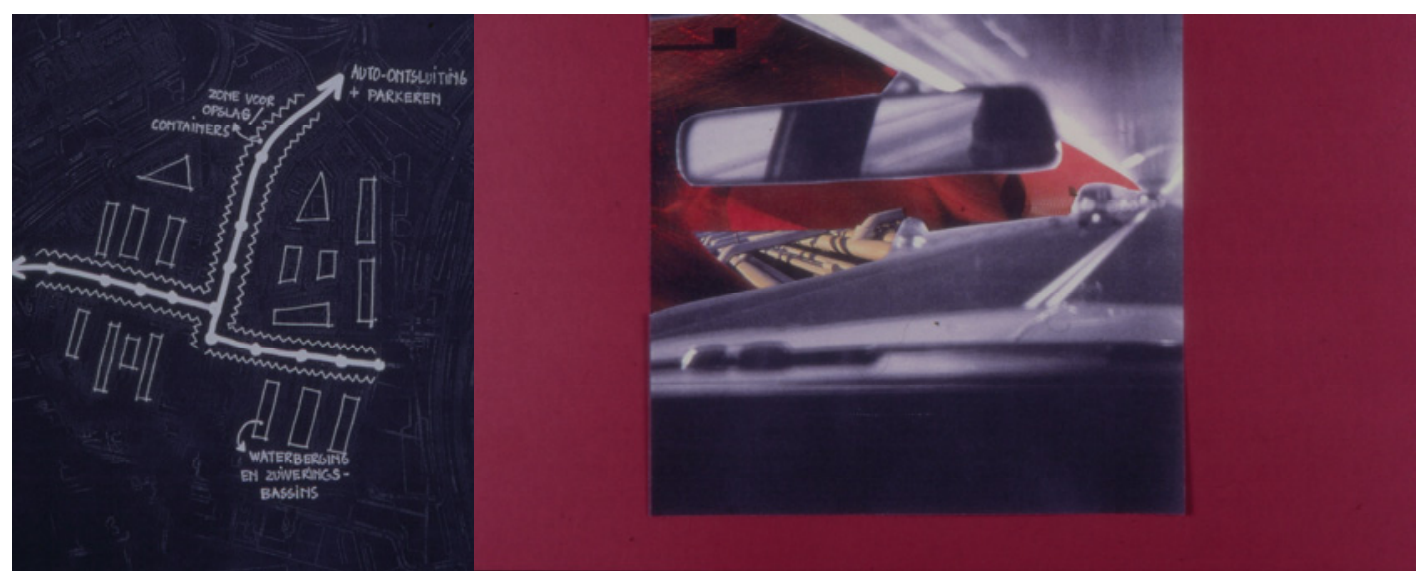

(a)
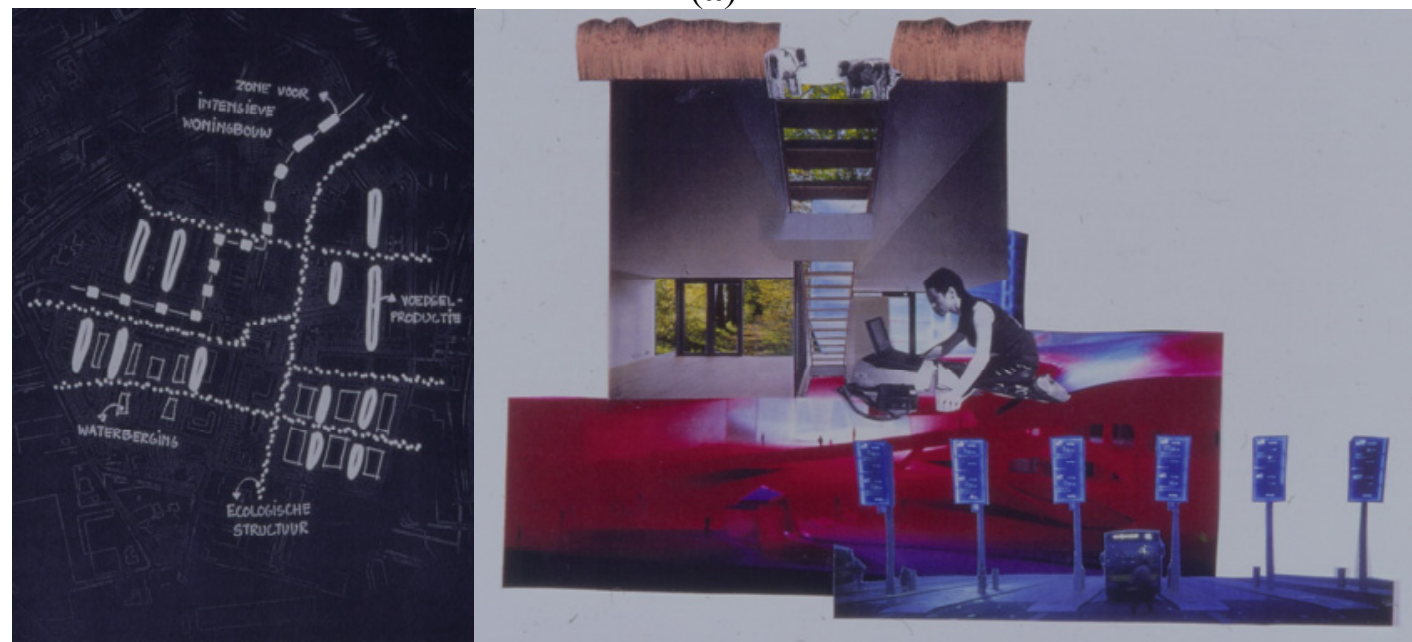

(b)

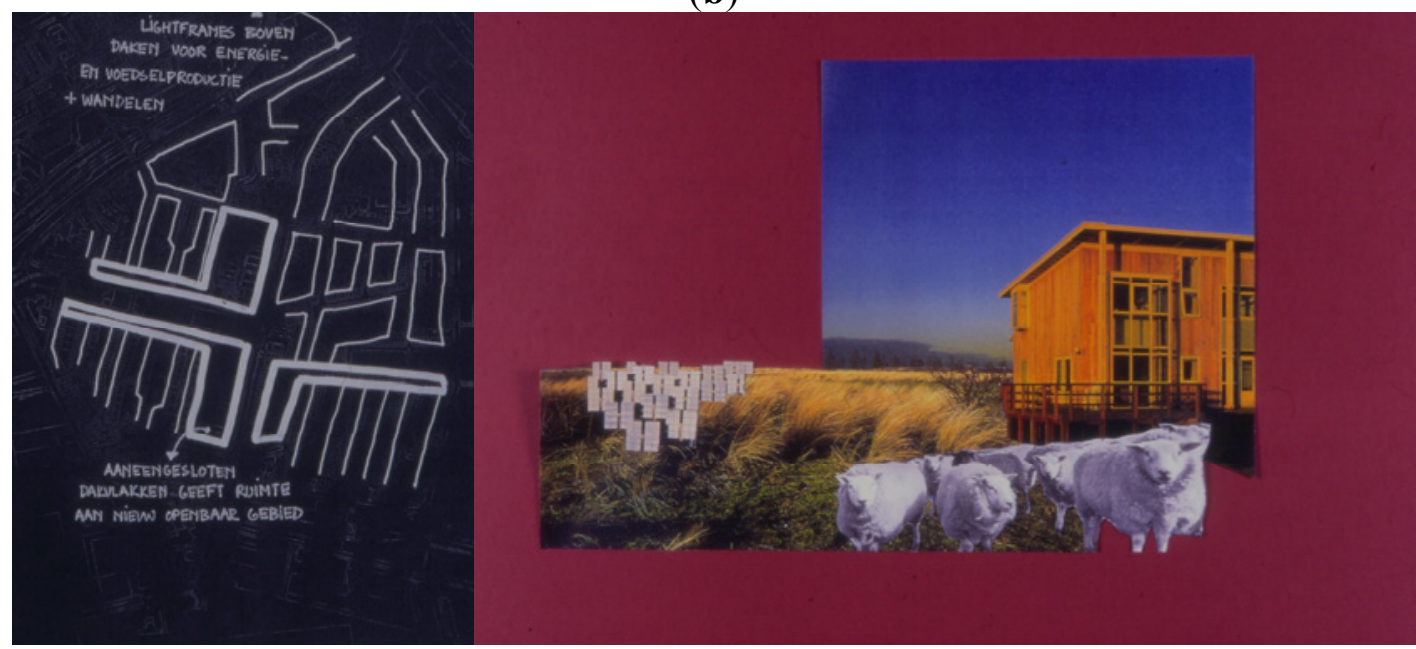

(c) 
Figure 4. Cont.

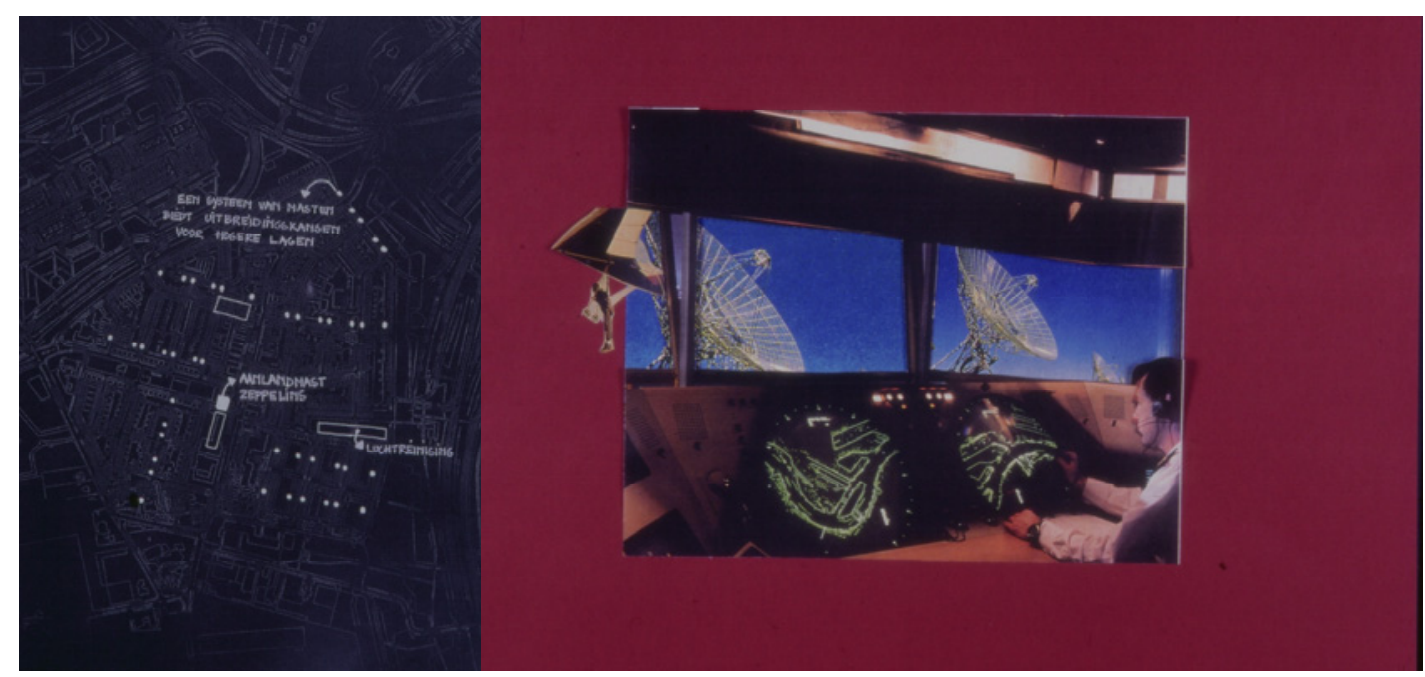

(d)

The first extra layer (the underground) provides extra space for waste transportation systems, parking, water storage, energy infrastructure and the delivery of goods by car, small trucks or via a tube-system. In the second extra layer, ground-level, use is doubled, offering space to intensify residential zones, to store water, to produce food, for ecological structures or to harvest renewable energy. The third extra layer is rooftops, on which lightweight frames can be installed to harvest energy (solar, biomass) and produce food. It also offers opportunities for recreation and leisure: take a stroll on the roof, enjoying the view or play a game of tennis, as Roger Federer and Andre Agassi already showcased on the $211 \mathrm{~m}$ high tennis court at the Burj-al-Arab building in Dubai. The connected roof space functions as an additional public area. The final, fourth, layer is up in the air: through the use of tall poles, spaces are created where alternative objects and functions (residential units, flying-bikes, helicopters, and solar panels) can be connected. There is also space for air cleaning appliances or zeppelin-landing points.

The combination of these extra spaces offers a wide variety for objects, and people to find appropriate locations where they can move. Together they increase the resilience of the entire system.

\subsection{Light Urbanism}

Light urbanism requires urban objects to be light, dismantable and modular, so that they can be taken up easily, moved to another place, and separated from infrastructure. This already takes place in the form of moveable or floatable houses, but not in a coherent way at an urban design scale. Elaborating the idea to "Colonize the Void" [96,97] of Randstad Holland with individual homes on large plots of gardens [98], while leaving behind the unsustainable and expensive Dutch idea to add two meters of sand for stabilizing reasons before building can commence, the planning model called "Lite Urbanism" [99-102] proposes an alternative. It consists of two typologies: "Campingland", a super-communal space that can be set up as a wood or nature reserve, and "Villageland", with large gardens around houses, enabling a village-like environment at low densities of seven to ten dwellings per hectare [99]. Both typologies make use of lighter roads and remove the majority of infrastructure, replacing telephone cables in the ground by mobile telephones, gas pipes by an electricity net 
connected to local alternative energy sources, and sewage plants at a distance by a water purification system in the garden. This form of light urbanism is especially useful when urban objects have a temporary location or function. Like a good traveller, a city should also be able to move without leaving a trace [54].

These principles, which allow residential units to move, have been used in the design for a light city in Houten, the Netherlands, constructed in a Design Lab. In this concept (Figure 5), autarkic light dwellings are proposed for a low-density development in a low and wet area. The light constructions and disconnection from heavy infrastructure make it possible to move houses, but also to deal with temporary wet conditions as a result of heavy rainfall. The houses are positioned on long and narrow parcels, which makes it possible to move "backwards", up onto the slightly higher parts, keeping them dry from sudden wet conditions. The light construction makes it also possible to lift the houses above temporary higher water levels.

Figure 5. Light urbanism in the light city in Houten, the Netherlands.

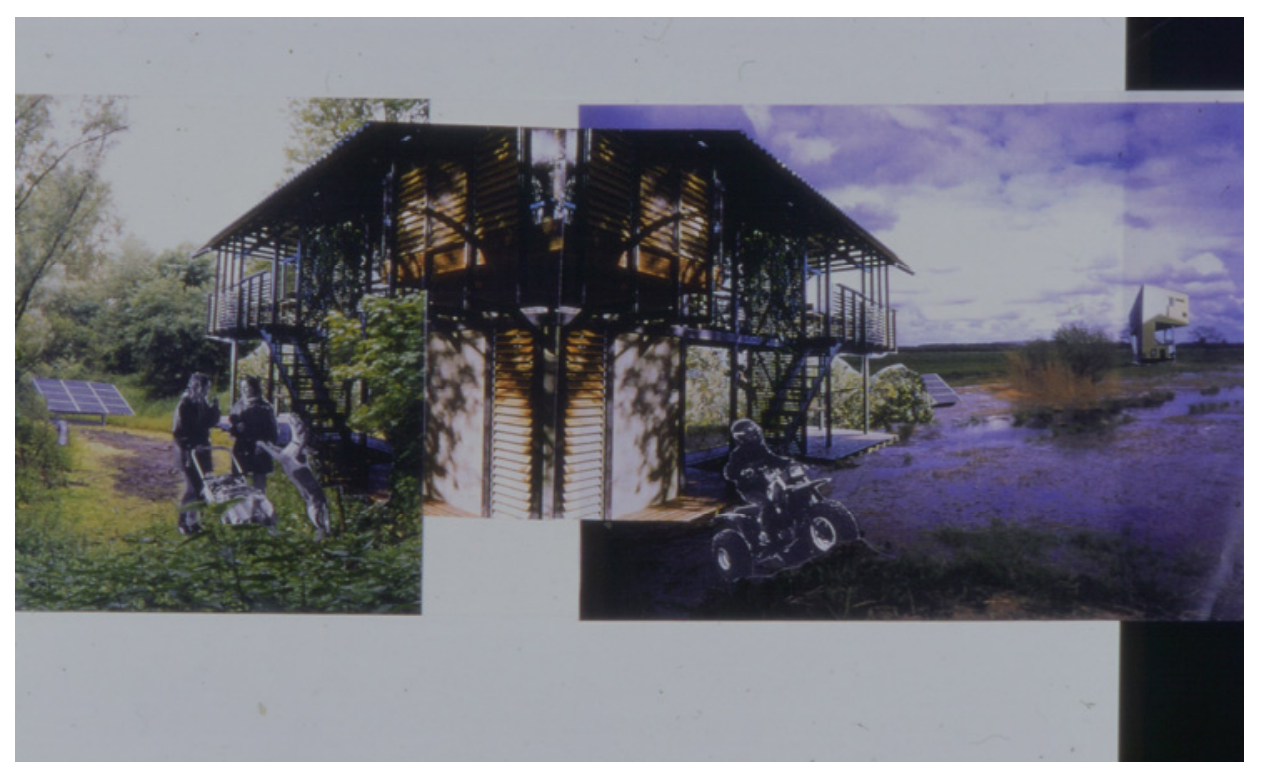

\subsection{The Empty City}

The third concept is the empty city [103]. In this example, an outdated neighbourhood, Hoge Vucht in the city of Breda, has been used to recreate viability and liveability by replacing dysfunctional elements (which create empty, vacant spaces in the city without turning it into a ghost town) by new modules and urban objects, increasing adaptability and enhancing sustainability of the entire area (Figure 6). Instead of demolishing entire neighbourhoods and replacing them by something new, this approach makes only a part of these neighbourhoods redundant and open for new urban objects or plug-ins. These new objects could be sustainable replacements, such as better, greener buildings, or new functional components producing food or energy. Sometimes physical objects are "plugged-in", but it is also possible to change functionality without changing the built structures. 
Figure 6. The empty city [103]. (a) "The Vertical Restaurant". Dinner at the highest level. The entrées are served at ground level, coffee with cognac at the rooftop terrace. Every floor has its own course, leading to an evening-long dynamic program. With each course you encounter a new environment with plenty of rooms to choose your preferred dishes. The top is the finale, with its view over the city, splashing water and heated terrace; (b) "Out of the Row". Get three houses for the price of one! When your neighbours have left you could "use" two extra units. One and a half houses become your own and you may use the other one and a half while remaining in the ownership of the housing corporation. You are obliged to maintain the extra units and choose your desired use: a solar plant on the roof, mushrooms in the cellar, vegetables in the greenhouse on the first floor, or a handyman shop at ground level. These are all ways to earn some extra income. From a standard row of eight attached houses, the two middle units could be demolished, leaving two detached houses each the size of three original units. Instead of living in between neighbours you are suddenly surrounded by green space.

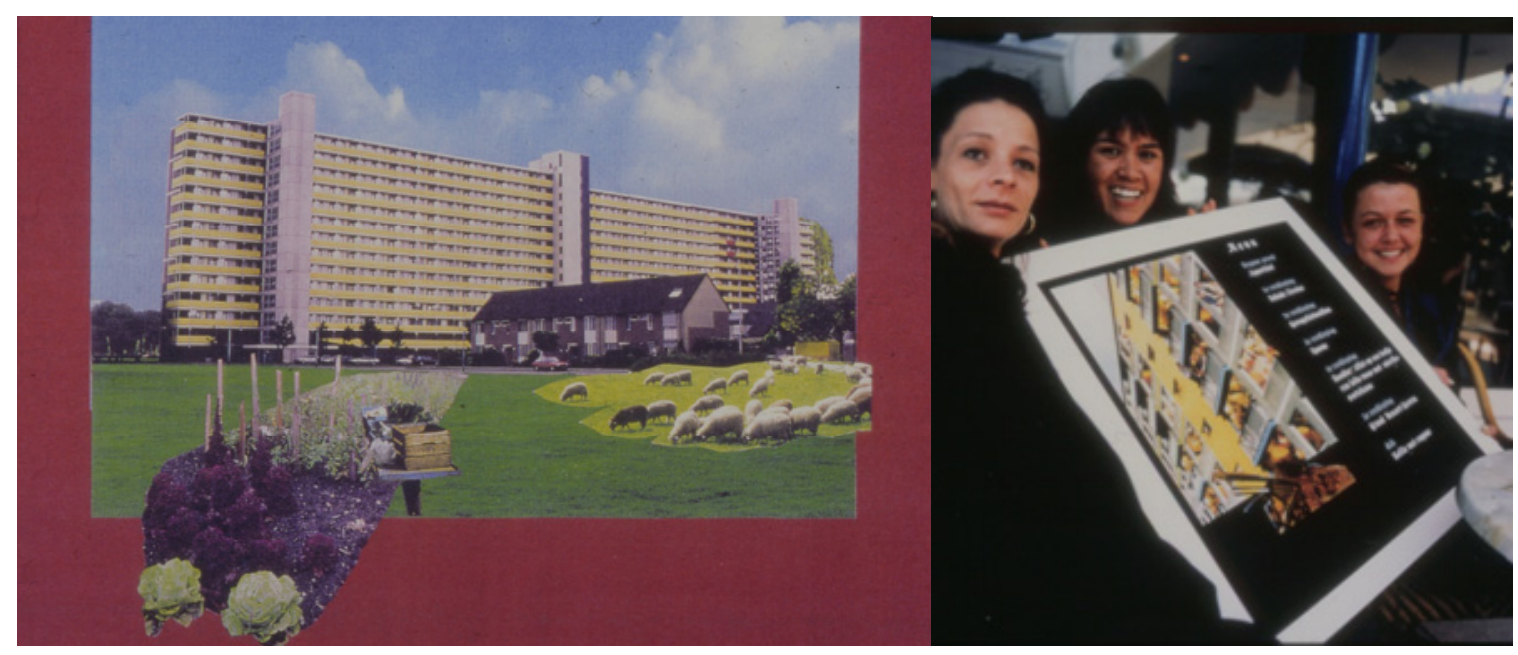

(a)

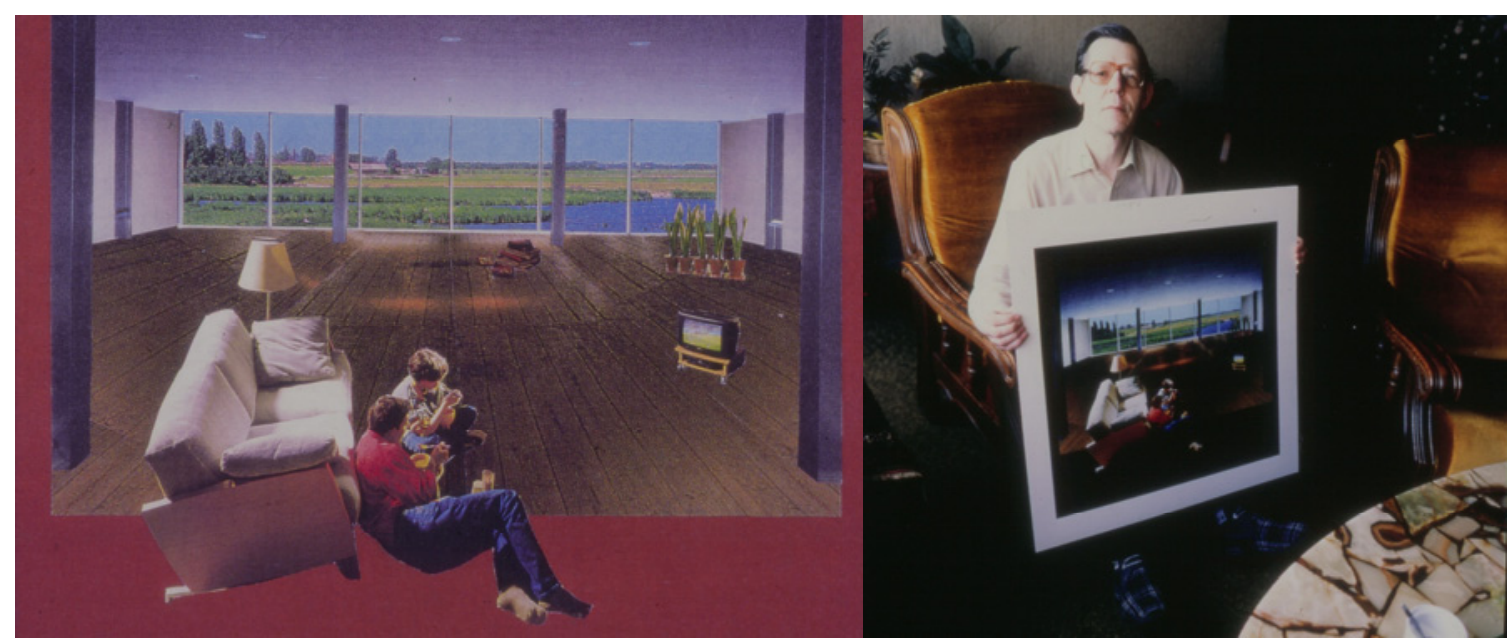

(b)

This leads to increased diversity in the neighbourhood, enriching an, often monotone, environment with a range of new objects and functions. In between existing high-rise buildings, abandoned green 
spaces are replaced by agricultural production, which provides local food to a vertical restaurant, where dinner ends at the top floor of the same high-rise building (see Box A). The existing small flats in these high-rise buildings are rearranged into double-sized large apartments, with a huge floor space and a great view. Low-rise attached houses are deconstructed and reassembled to extend the size of the individual homes and to plug in agricultural or energy harvesting units in between (see Box B).

Box A "The Vertical Restaurant"

Dinner at the highest level. The entrées are served at ground level, coffee with cognac at the rooftop terrace. Every floor has its own course, leading to an evening-long dynamic program. With each course you encounter a new environment with plenty of rooms to choose your preferred dishes. The top is the finale, with its view over the city, splashing water and heated terrace.

\section{Box B "Out of the Row"}

Get three houses for the price of one! When your neighbours have left you could 'use' two extra units. One and a half houses become your own; the other one and a half may be used by you while remaining in the ownership of the housing corporation. You are obliged to maintain the extra units and choose your desired use: a solar plant on the roof, mushrooms in the cellar, vegetables in the greenhouse on the first floor, or a handyman shop at ground level. These are all ways to earn some extra income. From a standard row of eight attached houses, the two middle units could be demolished, leaving two detached houses each the size of three original units. Instead of living in between neighbours you are suddenly surrounded by green space.

These transformations, despite their aim of increasing sustainability, can be quite confronting for local citizens. In this design project, people were therefore invited to literally stand model, by having their picture taken, for a specific transformation (Figure 6). Every specific spatial modification proposed in the neighbourhood was printed on foam boards was explained to citizens, before they were taken on picture, created around 25 "change stories" increased understanding and support for the design project.

\section{Current Constraints}

The proposal of a Dismantable City is a new concept and it is obvious that it cannot be implemented immediately due to several considerable constraints.

First, the current technological conditions in cities are not conducive to dismantability. Many of the city elements are difficult to loosen. Most buildings are fixed to the underground or next-door neighbours. In addition, the majority of the infrastructure is inextricably connected to its environment. Current practice in building infrastructure and buildings aims to strengthen constructions, which makes them inevitably more strongly connected to their surroundings. These construction "habits" are not easily changed. To speculate on how to get around this constraint is allowing building of moveable objects free of the land-use plan or building codes, e.g., when a developer, builder or contractor proposes a construction that can easily move to another place, it doesn't have the restrictions another, more fixed, object has. The building code must be abandoned for moveable objects. 
Secondly, there are social constraints. Only a limited number of people are willing to live in a place that will potentially move. Despite the romance of living on a houseboat or a ship, in reality not many people choose a floating residence, principally because few are familiar with the potential safety benefits. Moreover, these types of houses are currently not available in large numbers. In practice, only very specific and small projects that are owned and developed by the initiators are being developed. This means that individuals need to put a lot of effort into developing a project themselves. At the same time, ordinary fixed houses are available in large numbers, making them a more accessible option for an average person. A way to mitigate this effect is to offer spectacular zones, such as on the beach, dune tops, hilltops and more places that are vulnerable but with great views, to houses that are easy to move and relocate.

The third constraint is found in the current regulatory frameworks, which prevent the development of moveable urban elements. In the majority of cases, land use is regulated, determining what uses are allowed and, more importantly, prohibited. Changing the permissible land use requires revision of the plan, which is generally not possible within the term of the plan. Quick alterations in use are not supported, which makes it difficult to allow short-term change and/or reverse the change soon after. It is even more difficult to regulate multiple uses for a given area, alternating between two or more functions. To speculate a bit more, the legal framework must be adjusted to create the possibility of double land-use and the permission of temporary use.

These constraints are current and probably not easy to abrogate, but must be considered in order to create the space to respond to unprecedented occurrences. As long as these constraints imply creating an inflexible city, the city cannot respond, or even anticipate a future that is increasingly uncertain.

\section{Conclusion}

The Dismantable City is an innovative concept for building more resilient cities. It marks a fundamental shift in urban design. From the comprehensive and predictable planning practice in the technical-rational era, the Dismantable City absorbs interferences and provides flexibility. This break with history is necessary because current environmental issues are severe and demand new concepts. Extreme events, of which we expect many in the future, simply play around with our existing cities. The way our current cities are built is not only unsustainable, with a high metabolism, but also lacks the flexibility to be adjusted when necessary. This article has only given a first glimpse of the potential to rebuild our cities in a more resilient way and it is obvious that more work needs to be done in order to make this proposition more realistic. However, it is also obvious that continuation of current practices only leads to repetition in urban design and implies that we keep on rebuilding our cities after disasters. Fundamental rethinking of the way our cities are built is therefore essential and will create less vulnerable communities, and also neighbourhoods that are more interesting to live in, socially more inclusive and ecologically more productive.

Some questions remain to be answered in future research and experiments:

(1) Further design experiments are necessary to discover the conditions for dismantable cities in practical applications and to explore the potential to build realistic examples.

(2) The urban fabric, being part of a flexible and changeable environment is, in itself, subject to change. Elaboration is required to discover what ultra-high adaptability of urban environments 
might comprehend. Dynamic modelling might shine a light on eventual general rules and likely configurations.

(3) The urban metabolism model as it has been approached in this article, assumes that increased mobility of urban elements leads to a greater flexibility of and in cities, allowing for a more efficient metabolism, e.g., lesser and better quality of resources required and leading to less waste, and better liveability (for example: safety) of the city, which implies a more sustainable city. However, further research is required to estimate metabolisms of pilot studies in order to underpin this assumption.

(4) Despite research is not yet available on the metabolism of the Dismantable City, a comparison with a "rebuildable" city, e.g., the energy and materials it takes to rebuild a city after a disaster has destroyed the city, could deliver insights in the assumed benefits for the metabolism of the Dismantable City.

(5) The main future challenge for engineering consultants and companies is to overcome and further research the technical constraints of creating more mobile urban objects.

The Dismantable City faces challenges, but given that the majority of the current global population lives in urban environments and faces the impact of climate change, realisation of highly resilient urban environments in the form of Dismantable Cities could represent a very attractive future for many. Especially when cities grow fast, the mobility of urban objects could prove useful, as detached buildings and urban objects are easier, lighter, faster and cheaper to build. These objects allow a fast building pace and, as these rapid urban developments are often located in vulnerable zones for the impacts of climate change, offer the chance to relocate the city, or neighbourhoods, more easily. Moreover, moveable objects are less susceptible to hazards as they are lighter and could even anticipate a hazard by simply moving away.

\section{Conflicts of Interest}

The authors declare no conflict of interest.

\section{References}

1. Walker, B.; Holling, C.S.; Carpenter, S.R.; Kinzig, A. Resilience, adaptability and transformability in social-economic systems. Ecol. Soc. 2004, 9, 5. Available online: http://www.ecologyandsociety.org/vol9/iss2/art5/ (accessed on 21 February 2010).

2. Walker, B.; Salt, D. Resilience Thinking; Island Press: Washington, DC, USA, 2006.

3. Post Carbon Institute. Resilience. Available online: www.resilience.org (accessed on 2 March 2012).

4. Carver, C.S. Resilience and thriving: Issues, models and linkages. J. Soc. Issues 1998, 54, 245-266.

5. Tugade, M.M.; Fredrickson, B.L.; Feldman Barrett, L. Psychological resilience and positive emotional granularity: Examining the benefits of positive emotions on coping and health. J. Personal. 2004, 72, 1161-1190.

6. Mubeen, A. Mechanics of Solids, 2nd ed.; Pearson Education India: Delhi, India, 2011. 
7. Hollnagel, E., Woods, D.D., Leveson, N., Eds.; Resilience Engineering: Concepts and Precepts; Ashgate Publishing Ltd: Aldershot, ON, Canada, 2006.

8. Newman, P.W.; Birrell, R.; Homes, D.; Mathers, C.; Newton, P.; Oakley, G.; O’Connor, A.; Walker, B.; Spessa, A.; Tait, D. Human settlements. In Australia: State of the Environment 1996; Taylor, R., Ed.; Department of Environment, Australian Government: Canberra, ACT, Australia, 1996; Chapter 3, pp. 1-57.

9. Newman, P.; Beatley, T.; Boyer, H. Resilient Cities, Responding to Peak Oil and Climate Change; Island Press: Washington, DC, USA, 2009.

10. Holling, C.S. Understanding the complexity of economic, ecological and social systems. Ecosystems 2001, 4, 390-405.

11. The Resilience Alliance. Adaptive Cycle. Available online: www.resalliance.org/index.php/ adaptive_cycle (accessed on 2 March 2012).

12. Department for Environment, Food \& Rural Affairs (DEFRA). UK Climate Change Risk Assessment 2012; The Stationery Office Limited: London, UK, 2012.

13. KPMG. Australia Report: Risk Landscape. Availuable online: www.kpmg.com/au/en/ issuesandinsights/articlespublications/australia-report/pages/risk-landscape-2012.aspx (accessed on 12 October 2013).

14. Roggema, R. Swarm Planning: The Development of a New Planning Methodology to Deal with Climate Adaptation. Ph.D. Thesis, Delft University of Technology and Wageningen University and Research Center, Delft, the Netherlands, 2012.

15. Biggs, C.; Ryan, C.; Bird, J.; Trudgeon, M.; Roggema, R. Visions of Resilience: Design-Led Transformation for Climate Extremes; NDR-Final Report; The University of Melbourne: Melbourne, VIC, Australia, 2014.

16. Comfortable Chaos. Available online: http://comfortablechaos.tumblr.com (accessed on 3 May 2013).

17. Prigogine, I. Civilisation and democracy: Values, systems, structures and affinities. Futures 1986, 18, 493-507.

18. Prigogine, I.; Stengers, I. Order out of Chaos, 1st ed.; Bantam Books: New York, NY, USA, 1984.

19. Kauffman, S. The Origins of Order; Oxford University Press: New York, NY, USA, 1993.

20. Epstein, J.M.; Axtell, R.L. Growing Artificial Societies: Social Science from the Bottom up; Brookings Institution: Washington, DC, USA, 1996.

21. Lansing, J.S. Complex adaptive systems. Annu. Rev. Anthropol. 2003, 32, 183-204.

22. Liu, J.; Dietz, T.; Carpenter, S.R.; Alberti, M.; Folke, C.; Moran, E.; Pell, A.N.; Deadman, P.; Kratz, T.; Lubchenco, J.; et al. Complexity of coupled human and natural systems. Science 2007, 316, 1513-1516.

23. Nowotny, H. The increase of complexity and its reduction: Emergent interfaces between the natural sciences, humanities and social sciences. Theory Cult. Soc. 2005, 22, 15-31.

24. Urry, J. Complexity. Theory Cult. Soc. 2006, 23, 111-115.

25. Anderson, P. Complexity theory and organisation science. Organ. Sci. 1999, 10, 216-232.

26. Byrne, D. Complexity theory and planning theory: A necessary encounter. Plan. Theory 2003, 2, 171-178. 
27. Crawford, T.W.; Messina, J.P.; Manson, S.M.; O’Sullivan, D. Guest editorial. Environ. Plan. B 2005, 32, 792-798.

28. Duit, A.; Galaz, V. Governance and complexity-Emerging issues for governance theory. Governance 2008, 21, 311-335.

29. Levinthal, D.A.; Warglien, M. Landscape design: Designing for local action in complex worlds. Organ. Sci. 1999, 10, 342-357.

30. Montalvo, C. What triggers change and innovation? Technovation 2006, 26, 312-323.

31. O'Sullivan, D. Complexity science and human geography. Trans. Inst. Br. Geogr. NS 2004, 29, 282-295.

32. Plowman, D.A.; Baker, L.T.; Beck, T.E.; Kulkarni, M.; Solansky, S.T.; Travis, D.V. Radical change accidentally: The emergence and amplification of small change. Acad. Manag. J. 2007, 80, 515-543.

33. Pulselli, R.M.; Tiezzi, E. City Out of Chaos; WIT Press: Southampton, UK, 2009.

34. Richards, A. Complexity in physical geography. Geography 2002, 87, 99-107.

35. Teisman, G.R.; Klijn, E.H. Complexity theory and public management. Public Manag. Rev. 2008, 10, 287-297.

36. Timmermans, W.; van Dijk, T.; van der Jagt, P.; Onega Lopez, F.; Crecente, R. The unexpected course of institutional innovation processes: Inquiry into innovation processes into land development practices across Europe. Int. J. Des. Nat. Ecodynamics 2011, 6, 297-317.

37. Timmermans, W.; Ónega López, F.; Roggema, R. Complexity theory, spatial planning and adaptation to climate change. In Swarming Landscapes: The Art of Designing for Climate Adaptation; Roggema, R., Ed.; Springer: Heidelberg, Germany, 2012; pp. 43-65.

38. de Jonge, J. Landscape Architecture between Politics and Science, an Integrative Perspective on Landscape Planning and Design in the Network Society. Ph.D. Thesis, Wageningen University, Amsterdam, the Netherlands, 2009.

39. de Roo, G.; Porter, G. Fuzzy Planning, the Role of Actors in a Fuzzy Governance Environment; Ashgate Publishing: Burlington, VT, Canada, 2007.

40. Roggema, R.; van den Dobbelsteen, A. Swarm planning: Development of a new planning paradigm, which improves the capacity of regional spatial systems to adapt to climate change. In Proceedings of the World Sustainable Building Conference (SB08), Melbourne, VIC, Australia, 21-25 September 2008.

41. Timmermans, W. Crisis and innovation in sustainable urban planning. In Advances in Architecture; WIT-Press: Southampton, UK, 2004; Volume 18, pp. 53-63.

42. Odum, H.T. Systems Ecology: An Introduction; John Wiley and Sons: New York, NY, USA, 1983.

43. Portugali, J. Self-Organisation and the City; Springer-Verlag: Berlin/Heidelberg, Germany, 2000.

44. Tjallingii, S.P. Ecopolis: Strategies for Ecologically Sound Urban Development; Backhuys Publishers: Leiden, the Netherlands, 1993.

45. Wolman, A. The metabolism of cities. Sci. Am. 1965, 213, 178-193.

46. Newman, P.W.G. Sustainability and cities: Extending the metabolism model. Landsc. Urban Plan. 1999, 44, 219-226. 
47. Minx, J.; Creutzig, F.; Medinger, V.; Ziegler, T.; Owen, A.; Baiocchi, G. Developing a Pragmatic Approach to Assess Urban Metabolism in Europe; A Report to the European Environment Agency; SEI: Stockholm, Sweden; TU Berlin: Berlin, Germany, 2010.

48. Newman, P. The environmental impact of cities. Environ. Urban. 2006, 18, 275-295.

49. Newton, P.W., Ed. Re-Shaping Cities for a More Sustainable Future; Research Monograph 6; Australian Housing and Urban Research Institute (AHURI): Melbourne, VIC, Australia, 1997.

50. Newton P.; Flood, J.; Berry, M.; Bhatia, K.; Brown, S.; Cabelli, A.; Gomboso, J.; Higgins, J.; Richardson, T.; Ritchie, V. Environmental indicators for national state of the environment reporting-Human settlements. In Australia: State of the Environment (Environmental Indicator Reports); Department of Environment, Australian Government: Canberra, ACT, Australia, 1998; pp. 1-188.

51. Newton, P.W.; Baum, S.; Bhatia, K.; Brown, S.K.; Cameron, A.S.; Foran, B.; Grant, T.; Mak, S.L.; Memmott, P.; Mitchell, V.C.; Neate, K.; et al. Human settlements. In Australia State of the Environment Report 2001 (Theme Report); CSIRO Publishing on Behalf of the Department of the Environment, Australian Government: Canberra, ACT, Australia, 2001; pp. 1-198.

52. Niza, S.; Rosado, L.; Ferrão, P. Urban metabolism. J. Ind. Ecol. 2009, 13, 384-405.

53. Tomásek, W. Die Stadt als Oekosystem; Überlegungen zum Vorentwurf Landschafsplan Köln (The city as ecosystem; considerations about the scheme of the Landscape design Cologne). Landsch. Stadt 1979, 11, 51-60.

54. Kristinsson, J. Integrated Sustainable Design; van den Dobbelsteen, A., Ed.; Delft Digital Press: Delft, the Netherlands, 2012.

55. Merry, U. Coping with Uncertainty: Insights from the New Sciences of Chaos, Self-Organisation and Complexity; Praeger: Westport, CT, USA, 1995.

56. Davy, B. Plan it without a condom! Plan. Theory 2008, 7, 301-317.

57. Gunder, M. Fake it until you make it, and then... Plan. Theory 2011, 10, 201-212.

58. Newman, S. Post-anarchism and space: Revolutionary fantasies and autonomous zones. Plan. Theory 2011, 10, 344-365.

59. Boelens, L. Theorizing practice and practising theory: Outlines for an actor-relational-approach in planning. Plan. Theory 2010, 9, 28-62.

60. Miraftab, F. Insurgent planning: Situating radical planning in the Global South. Plan. Theory 2009, 8, 32-50.

61. Timmermans, W.; Cilliers, J.; Slijkhuis, J. Planning by Surprise: The Values of Green Spaces in Towns and Cities; Van Hall Larenstein: Velp, the Netherlands, 2012.

62. Cook, P.; Webb, M. Archigram; Princeton Architectural Press: Princeton, NJ, USA, 1999.

63. Sadler, S. Archigram: Architecture without Architecture; MIT Press: Cambridge, UK, 2005.

64. Superuse Studios. Available online: www.superuse-studios.com (accessed on 4 May 2013).

65. Uhde, R. Secondhand architektur. Aface 2012, 6, 35-36.

66. Leroux, K.; Seldman, N. Deconstruction, Salvaging Yesterday's Buildings for Tomorrow's Sustainable Communities; Institute for Local Self-Reliance: Washington, DC, USA, 1999.

67. Oosterhuis, K. Swarm architecture. In Game, Set and Match II, On Computer Games, Advanced Geometries and Digital Technologies (No.2); Oosterhuis, K., Feireiss, L., Themans, M., Eds.; Episode Publishers: Rotterdam, the Netherlands, 2006; Chapter II, pp. 14-28. 
68. Oosterhuis, K. Towards a New Kind of Building, A Designer's Guide to Nonstandard Architecture; NAI Uitgevers: Rotterdam, the Netherlands, 2011.

69. Oosterhuis, K. Hyperbody: First Decade of Interactive Architecture; Ram Publications: Santa Monica, CA, USA, 2012.

70. Wiki-Habitat 67. Available online: http://en.wikipedia.org/wiki/Habitat_67 (accessed on 7 May 2013).

71. JafUd.org. Available online: www.jafud.org (accessed on 27 December 2006).

72. Roggema, R. Swarming landscapes. In Swarming Landscapes: The Art of Designing for Climate Adaptation; Roggema, R., Ed.; Springer: Heidelberg, Germany, 2012; pp. 167-193.

73. Portugali, J. Complexity theory as a link between space and place. Environ. Plan. A 2006, $38,647-664$.

74. Portugali, J. Learning from paradoxes about prediction and planning in self-organising cities. Plan. Theory 2008, 7, 248-262.

75. van Ginneken, J. De kracht van de Zwerm (The Power of the Swarm); Antwerpen: Amsterdam, the Netherlands, 2009.

76. Fisher, L. The Perfect Swarm, the Science of Complexity in Everyday Life; Basic Books: New York, NY, USA, 2009.

77. Miller, P. The Smart Swarm; The Penguin Group: New York, NY, USA, 2010.

78. Gladwell, M. The Tipping Point; Little, Brown and Company, Time Warner Book Group: New York, NY, USA, 2000.

79. Scheffer, M. Critical Transitions in Nature and Society; Princeton University Press: Princeton, NJ, USA, 2009.

80. Barabási, A.-L. Linked: How Everything is Connected to Everything Else and What it Means for Business, Science, and Everyday Life; Penguin Group: London, UK, 2002.

81. Bianconi, G.; Barabási, A.-L. Competition and multiscaling in evolving networks. Europhys. Lett. 2001, 54, 436-442.

82. Broder, A.; Kumar, R.; Maghoul, F.; Raghavan, P.; Rajagopalan, S.; Stata, R.; Tomkins, A.; Wiener, J. Graph structure in the Web. Comput. Netw. 2000, 33, 309-320.

83. Erdós, P.; Rényi, A. On the evolution of random graphs. Publ. Math. Inst. Hung. Acad. Sci. 1960, 5, 17-61.

84. Solé, R.V.; Pastor-Satorras, R.; Smith, E.; Kepler, T.B. A model of large-scale proteome evolution. Adv. Complex Syst. 2002, 5, 43-54.

85. Watts, D.J.; Strogatz, S.H. Collective dynamics of "small-world" networks. Nature 1998, 393, 440-442.

86. Roggema, R.; Vermeend, T.; van den Dobbelsteen, A. Incremental change, transition or transformation? Optimising change pathways for climate adaptation in spatial planning. Sustainability 2012, 4, 2525-2549.

87. Manson, S.M. Simplifying complexity: A review of complexity theory. Geoforum 2001, 32, 405-414.

88. Cohen, J.; Stewart, I. The Collapse of Chaos: Discovering Simplicity in a Complex World; Penguin Books: London, UK, 1995. 
89. Langton, C.G.; Taylor, C.; Farmer, J.D.; Rasmussen, S. Artificial Life II (Studies in the Sciences of Complexity Proceedings); Santa Fe Institute: Redwood City, CA, USA, 1992; Volume 10.

90. Mitchell Waldrop, M. Complexity. The Emerging Science at the Edge of Order and Chaos, 1st ed.; Simon \& Schuster: New York, NY, USA, 1992.

91. Roggema, R. Swarming landscapes, new pathways for resilient cities. In Proceedings of the 4th International Urban Design Conference-Resilience in Urban Design, Surfers Paradise, Gold Coast, QLD, Australia, 23 September 2011.

92. Roggema, R. Modelling the Benefits of Swarm Planning, a Dynamic Way of Planning for Future Adaptation to Climate Change Impacts. Rubicon Research Proposal (Granted); NWO: Den Haag, the Netherlands, 2012.

93. Tjallingii, S.P. Carrying structures: Urban development guided by water and traffic networks. In Shifting Sense, Looking Back to the Future in Spatial Planning; Hulsbergen, E.D., Klaasen, L.T., Kriens, L., Eds.; Techne Press: Amsterdam, the Netherlands, 2005; pp. 355-368.

94. Tjallingii, S.P.; de Roo, G. Complexity and carrying structures-Learning-by-doing in urban planning. Presented at AESOP Working Group, Stockholm, Sweden, 26-27 February 2010.

95. Aiello, C.; Aldridge, P.; Deville, N.; Solt, A.; Lee, J.S. Evolo Skyscrapers; Evolo Inc.: Los Angeles, CA, USA, 2012; Volumes 1 and 2.

96. Geuze, A. Wildernis (Wilderness). In Alexanderpolder, New Urban Frontiers; Devolder, A.-M., Ed.; Uitgeverij THOTH: Bussum, the Netherlands, 1993; pp. 96-105.

97. van Dijk, H.; Geuze, A.; Bindels, E.; Musch, J. Colonizing the Void; NAI Publishers: Rotterdam, the Netherlands, 1996.

98. Lootsma, B. Synthetic regionalisation: The Dutch landscape toward a second modernity. In Recovering Landscape, Essays in Contemporary Landscape Architecture, 1st ed.; Cornor, J., Ed.; Princeton Architectural Press: New York, NY, USA, 1999; pp. 250-274.

99. Maas, W. Light urbanism. Archis 1997, 11, 74-79.

100. Moreno Mansilla, L.; Tuñon, E. Una conversación con Winy Maas, Jacob van Rijs y Nathalie de Vries (A conversation with Winy Maas, Jacob van Rijs and Nathalie de Vries). In MVRDV; Levene, R.C., Márquez Cecilia, F., Eds.; El Croquis: Madrid, Spain; 1997; Volume 58, pp. 6-25.

101. Maas, W.; van Rijs, J.; Koek, R. Permanence. In Farmax: Excursions on Density; 010 Publishers: Rotterdam, the Netherlands, 1998; pp. 34-51.

102. MVRDV. Architects \& Kristinsson Engineers. Midden-IJsselmonde, Lichte Stedebouw. Smitshoek en de toekomst van de Nederlandse uitbreidingswijk (Midden-IJsselmonde, Light Urban Planning. Smitshoek and the future of the Dutch new development district). In Rotterdam 2045, Visies op de Toekomst van Stad, Haven en Region (Rotterdam 2045, Visions of the Future for the Town, Harbour and Region); Boekraad, C., van Es, W., Eds.; Netherlands Architecture Institute (NAI): Rotterdam, the Netherlands, 1995.

103. Roggema, R.; Timmermans, W.; Oost, L. Transformatie Hoge Vught. (Transformation of Hoge Vught); IBN Rapport 450; IBN-DLO: Wageningen, the Netherlands, 1999.

(C) 2014 by the authors; licensee MDPI, Basel, Switzerland. This article is an open access article distributed under the terms and conditions of the Creative Commons Attribution license (http://creativecommons.org/licenses/by/3.0/). 